\title{
MODEL PREDIKSI JUMLAH PENDERITA COVID-19 DENGAN LAJU PERTUMBUHAN TAK KONSTAN
}

\author{
SYAFIRA KHAIRUNNISA, SUSILA BAHRI, RIRI LESTARI \\ Program Studi S1 Matematika, \\ Fakultas Matematika dan Ilmu Pengetahuan Alam, Universitas Andalas, \\ Kampus UNAND Limau Manis Padang, Indonesia. \\ email : syafirakhairunnisa68@gmail.com,susilabahri@sci.unand.ac.id, \\ ririlestari@sci.unand.ac.id
}

Diterima 15 September 2020 Direvisi 14 Oktober 2020 Dipublikasikan 21 Oktober 2020

\begin{abstract}
Abstrak. Data laju pertumbuhan Covid-19 yang tak konstan digunakan untuk konstruksi model penentuan jumlah penderita virus tersebut. Model ini dihasilkan melalui pendekatan teori graf dimana titik-titik pada graf menyatakan dua himpunan yaitu himpunan orang yang terinfeksi dan orang yang rentan terinfeksi. Sedangkan sisi-sisinya menunjukkan terjadinya proses menginfeksi. Model ini kemudian disimulasikan dengan menggunakan program Matlab untuk memprediksi jumlah orang terinfeksi pada periode ke-n.

Kata Kunci: Covid-19, Model Matematika, Prediksi Jumlah Penderita
\end{abstract}

\section{Pendahuluan}

Diakhir tahun 2019, perhatian dunia difokuskan dengan merebaknya virus baru. World Health Organization (WHO) menamakan virus tersebut dengan Severe acute respiratory syndrome coronavirus-2 (SARS-CoV-2). Virus yang pertama kali muncul di Wuhan (China) ini menimbulkan penyakit yang dikenal dengan Coronavirus Desease 2019 (Covid-19) [6].

Menurut World Health Organization (WHO), penyebaran virus Covid-19 dapat terjadi melalui adanya cipratan air liur atau lendir dari penderita virus Covid-19 yang keluar pada saat flu atau batuk bahkan saat berbicara yang kemudian masuk ke tubuh orang lain melalui mata, hidung, dan mulut. Organisasi tersebut juga menyatakan bahwa penyakit mematikan tersebut telah menyebar sangat cepat di seluruh dunia termasuk Indonesia.

Berbagai penelitian telah dilakukan oleh para peneliti untuk melihat bagaimana penyebaran ataupun pertumbuhan dari virus Covid-19 ini. Bhapkar dkk.[1] pada bulan April 2020 telah mengkonstruksikan model yang diungkapkan dengan graf dengan memperhatikan penyebaran wabah Covid-19 sehingga diperoleh jenis model

*penulis korespondensi 
graf virus dan model prediksi jumlah penderita Covid-19 dengan laju pertumbuhan tak konstan.

Penelitian ini mengelaborasi dari yang telah diteliti oleh Bhapkar, dkk. [1]. Peneliti mengumpulkan nilai laju pertumbuhan yang diperoleh dari data Dummy, memprediksi jumlah pasien terinfeksi Covid-19 kemudian mengonstruksikannya ke dalam model graf virus sebagaimana yang telah diperoleh oleh Bhapkar, dkk. [1].

\section{Landasan Teori}

\subsection{Definisi dan Terminologi Graf}

Graf $G$ dapat dinyatakan sebagai pasangan himpunan $(V(G), E(G))$ dimana $V(G)$ adalah himpunan tak kosong yang elemennya disebut vertex dari $G$, dan $E(G)$ merupakan pasangan tak terurut dari vertex berbeda yang disebut sisi dari $G$. Banyaknya vertex pada graf $G$ yang dinotasikan dengan $|V(G)|$ disebut orde. Banyaknya sisi pada graf $G$ yang dinotasikan dengan $|E(G)|$ disebut ukuran [2].

Dua vertex $u$ dan $v$ pada graf $G$ jika terhubung langsung oleh suatu sisi $e$, maka kedua vertex tersebut dikatakan bertetangga. Lingkungan vertex $v$ di $G$ adalah himpunan semua vertex yang bertetangga dengan $v[2]$.

Sisi ganda adalah dua atau lebih sisi yang menghubungkan dua vertex yang sama sedangkan loop adalah sisi yang dibentuk oleh dua vertex yang sama. Berdasarkan ada atau tidaknya loop atau sisi ganda pada suatu graf, graf secara umum dapat dikelompokkan menjadi graf sederhana dan graf tak sederhana. Graf sederhana merupakan graf yang tidak mengandung loop atau sisi ganda, sedangkan graf yang mengandung loop atau sisi ganda disebut graf tak sederhana [2].

Graf siklus atau graf lingkaran adalah graf sederhana yang setiap simpulnya berderajat dua. Graf siklus tidak memiliki loop atau sisi ganda karena graf siklus merupakan graf sederhana. Graf ini dilambangkan dengan $C_{n}$. Graf lengkap adalah graf sederhana yang setiap titiknya bertetangga dengan titik lainnya. Graf lengkap dengan $n$ buah titik dilambangkan dengan $K_{n}$, dengan $n \geq 1[2]$.

\subsection{Himpunan Variabel}

Suatu himpunan $S$ dinamakan himpunan variabel jika elemen dari himpunan $S$ berubah bersamaan dengan berubahnya waktu dan aturan. Oleh karena itu, himpunan $S$ bukan himpunan konstan. Perubahan kardinalitas himpunan tersebut berhubungan dengan waktu. Himpunan variabel biasanya dinotasikan dengan $S_{v}$. Berdasarkan kardinalitas, himpunan $S_{v}$, terdiri atas lima jenis himpunan salah satunya himpunan variabel stabil. Suatu himpunan variabel $S_{v}$ dikatakan himpunan variabel stabil jika $\left|S_{v}(t)\right|$ konstan, untuk sebarang waktu $t$. [1]

\subsection{Graf Partite dan Graf Variabel}

\section{Graf Partite}

Suatu graf $H$ adalah graf partite-n jika $V(H)=V_{1} \cup V_{2} \cup \cdots \cup V_{n}$, dimana semua $V_{i}$ disjoint untuk $i=1,2, \cdots, n$ dan tiap sisi dari $H$ memakai bersama vertex $V_{i}$ dan $V_{j}$ untuk $i \neq j[1]$. 


\section{Graf Variabel}

Suatu graf $H$ dikatakan graf variabel vertex jika $V(H)$ atau $E(H)$ adalah himpunanhimpunan variabel. Graf variabel disebut juga Graf- $V$ [1].

Graf- $V$ Bipartite

Suatu graf variabel $H$ dikatakan Graf-V bipartite jika [5]:

i. $V(H)=V_{1} \cup V_{2}$ dimana $V_{1}, V_{2}$ adalah himpunan variabel terpisah yang memiliki karakteristik yang berbeda.

ii. Terdapat sisi antara vertex-vertex $V_{1}$ dan $V_{2}$.

iii. Tidak ada sebarang sisi antara vertex $V_{1}$ atau $V_{2}$.

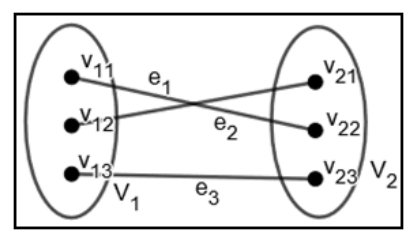

Gambar 1. Graf Bipartite

Berdasarkan Gambar 1, terdapat dua himpunan variabel $V_{1}$ dan $V_{2}$ yang memiliki karakteristik yang berbeda, $e_{1}, e_{2}$, dan $e_{3}$ merupakan sisi-sisi yang menghubungkan vertex-vertex elemen himpunan $V_{1}$ dan $V_{2}$.

Graf- $V$ n-Partite

Suatu graf variabel $H$ dikatakan Graf- $V$-partite jika [1]:

i. $V(H)=V_{1} \cup V_{2} \cup V_{3} \cup \cdots \cup V_{n}$ dimana $V_{1}, V_{2}, V_{3}, \cdots, V_{n}$ adalah himpunan variabel terpisah yang memiliki karakteristik yang berbeda.

ii. Terdapat sisi antara vertex-vertex $V_{i}$ dan $V_{j}$ untuk $i, j$ dan $i \neq j$.

\subsection{Model Graf Virus I}

Graf- $V$ Bipartite $H$ dikatakan graf virus I (VRG-I) jika [1]:

i. $V(H)=I \cup N$, dimana $I$ adalah himpunan variabel vertex yang memiliki sifat khusus atau terinfeksi virus dan $N$ adalah himpunan variabel vertex yang tidak memiliki virus.

ii. Jika $x \in I$, memiliki sisi dengan vertex $y \in N$ atau sebaliknya maka y dipindahkan ke $I$ dan $N=N-\{y\}$.

iii. Jika $x \in I$, pulih karena perlakuan atau virusnya hilang, maka $x$ dipindahkan ke $N$ dan $N=N \cup\{x\}$.

Representasi graf virus I seperti Gambar 2 [1].

Berdasarkan Gambar 2, I merupakan himpunan orang-orang yang terinfeksi virus Covid-19, $N$ merupakan himpunan orang-orang yang rentan terinfeksi virus Covid-19. $i_{1}, i_{2}, i_{3}$, dan $i_{4}$ menunjukkan elemen-elemen dari himpunan orang yang terinfeksi virus Covid-19, sedangkan $n_{1}, n_{2}$, dan $n_{3}$ 


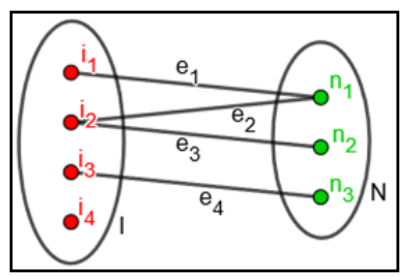

Gambar 2. Graf Virus I

menunjukkan elemen-elemen dari himpunan orang yang rentan terinfeksi Covid19. Elemen himpunan $I$ dapat berpindah menjadi elemen himpunan $N$ apabila elemen himpunan $I$ sembuh karena perlakuan maupun tanpa perlakuan. Elemen himpunan $N$ juga dapat berpindah menjadi elemen di himpunan $I$ apabila orang dari himpunan $N$ berinteraksi langsung dengan orang dari himpunan $I$, sehingga elemen himpunan $N$ terinfeksi virus Covid-19. Diasumsikan sisi-sisi $e_{1}, e_{2}, e_{3}$, menunjukkan terjadinya proses menginfeksi oleh elemen himpunan $I$ terhadap elemen himpunan $N$. Jadi, elemen-elemen dari himpunan $I$ maupun himpunan $N$ dapat berpindah sesuai kondisi.

\section{Pembahasan}

\subsection{Laju Pertumbuhan}

Laju pertumbuhan secara umum dapat berupa laju pertumbuhan konstan dan tak konstan. Nilai laju pertumbuhan virus Covid-19 tak konstan dapat disebabkan karena orang-orang terinfeksi virus Covid-19 tidak melakukan isolasi diri, orang yang rentan tidak mengikuti protokol kesehatan dari pemerintah, sehingga laju pertumbuhan setiap hari berubah meningkat atau menurun. Apabila masyarakat mengikuti protokol kesehatan yang ada, nilai laju pertumbuhan perharinya dapat menurun yang menunjukkan penyebaran virus Covid-19 semakin berkurang. Sebaliknya, apabila masyarakat tidak mengikuti protokol kesehatan, nilai laju pertumbuhan virus perharinya dapat terus meningkat.

Pada kenyataannya satu orang yang terinfeksi Covid-19 dapat menginfeksi satu orang yang rentan atau lebih, orang yang terinfeksi tersebut juga berkemungkinan tidak menginfeksi satupun orang yang rentan terinfeksi Covid-19. Pada penelitian ini diasumsikan orang yang terinfeksi virus Covid-19 menginfeksi hanya satu orang yang rentan atau tidak sama sekali dengan laju pertumbuhan tak konstan.

\subsection{Pertumbuhan Satu-satu}

Jika satu elemen aktif dari himpunan variabel menginfeksi hanya satu elemen aktif pada himpunan lain dalam suatu waktu, maka pertumbuhan tersebut dinamakan pertumbuhan satu-satu (pertumbuhan 1-1). $K_{1}$ adalah elemen aktif individu pada himpunan variabel $N$. 


\subsection{Pertumbuhan Tak Konstan}

Asumsikan terdapat laju pertumbuhan yang berbeda pada tiap periode waktu (hari) sebagaimana dinyatakan pada Tabel 1 berikut[1]. Misalkan $I_{0}$ adalah jumlah orang yang terinfeksi virus pada tahap awal, dan $I_{n}$ adalah jumlah orang yang terinfeksi virus pada hari ke- $n, R_{i}$ adalah laju pertumbuhan virus dalam periode waktu (hari) ke- $i$, dan $t_{i}$ adalah waktu (hari) ke- $i$ dengan $i=1,2, \cdots, n$.

Tabel 1. Laju Pertumbuhan Tak Konstan dan Interval Waktu

\begin{tabular}{|c|c|c|c|c|c|c|c|}
\hline Waktu $\left(t_{i}\right)$ & $t_{1}$ & $t_{2}$ & $t_{3}$ & $t_{4}$ & $\cdots$ & $t_{n-1}$ & $t_{n}$ \\
\hline Laju Pertumbuhan $\left(R_{i}\right)$ & $R_{1}$ & $R_{2}$ & $R_{3}$ & $R_{4}$ & $\cdots$ & $R_{n-1}$ & $R_{n}$ \\
\hline
\end{tabular}

Jumlah orang yang terinfeksi pada hari pertama adalah

$$
I_{1}=I_{0}+R_{1} I_{0}=\left(1+R_{1}\right) I_{0} .
$$

Selanjutnya, untuk interval waktu kedua dan ketiga berturut-turut adalah sebagai berikut:

$$
\begin{aligned}
& I_{2}=I_{1}+R_{2} I_{1}=\left(1+R_{2}\right)\left(1+R_{1}\right) I_{0}, \\
& I_{3}=I_{2}+R_{3} I_{2}=\left(1+R_{3}\right)\left(1+R_{2}\right)\left(1+R_{1}\right) I_{0} .
\end{aligned}
$$

Oleh karena itu, untuk interval waktu ke $n$, diperoleh model prediksi jumlah orang terinfeksi Covid-19 sebagai berikut:

$$
\begin{aligned}
I_{n} & =\left(1+R_{n}\right)\left(1+R_{n-1}\right)\left(1+R_{n-2}\right) \cdots\left(1+R_{1}\right) I_{0}, \\
& =I_{0} \prod_{i=1}^{n}\left(1+R_{i}\right) .
\end{aligned}
$$

\subsection{Perhitungan Jumlah Penderita Covid-19 dengan Laju Pertumbuhan Tak Konstan}

Berikut diberikan contoh aplikasi model dengan laju pertumbuhan tak konstan. Data laju pertumbuhan yang digunakan pada penelitian ini merupakan data yang diperoleh dari data Dummy. Data Dummy merupakan informasi yang tidak mengandung data berguna. Data Dummy dapat digunakan sebagai data pengganti yang bertujuan untuk pengujian.

Data dummy laju pertumbuhan tersebut dapat diperoses dengan Matlab untuk memperoleh prediksi jumlah pasien terinfeksi virus Covid-19 pada waktu (hari) ke$n$. Untuk memudahkan perhitungan jumlah orang yang terinfeksi Covid-19 untuk hari ke- $n$ digunakan Matlab dalam perhitungannya. Sintaks Matlab untuk menghitung jumlah orang yang terinfeksi Covid-19 pada waktu (hari) ke- $n$ ditunjukkan oleh Gambar 3.

Dengan menggunakan sintaks pada gambar 3, maka hasil prediksi jumlah pasien terinfeksi Covid-19 pada hari ke-1, 2, 15, dan 16 adalah seperti Gambar 4 berikut: 


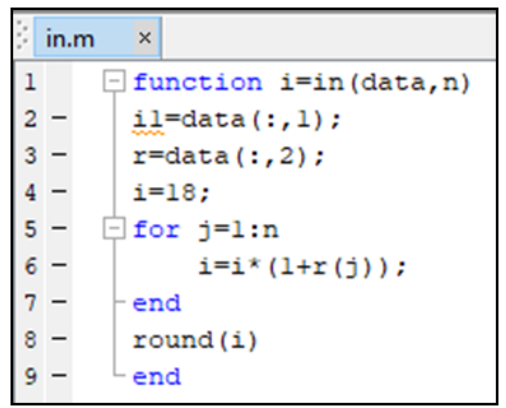

Gambar 3. Sintaks untuk Menghitung Jumlah Pasien Covid-19

\begin{tabular}{|c|c|}
\hline$\gg$ 1n (data, 1) & $\gg$ in (data, 15) \\
\hline ans - & ans - \\
\hline 22 & 54 \\
\hline ans - & ans = \\
\hline 21.6000 & 53.7612 \\
\hline$\gg$ in (data, 2) & $\gg$ in (Aata, 16) \\
\hline ans = & ans - \\
\hline 23 & 55 \\
\hline ans = & ans - \\
\hline 23.0407 & 55.4923 \\
\hline
\end{tabular}

Gambar 4. Prediksi Jumlah Pasien Terinfeksi Covid-19 Hari Ke-1, 2, 15, dan 16

\subsection{Model Graf Prediksi Jumlah Penderita Covid-19 dengan Laju Pertumbuhan Tak Konstan}

Perhitungan prediksi jumlah pasien terinfeksi Covid-19 yang telah diperoleh dengan Matlab dapat direpresentasikan ke dalam model graf pertumbuhan satu-satu.

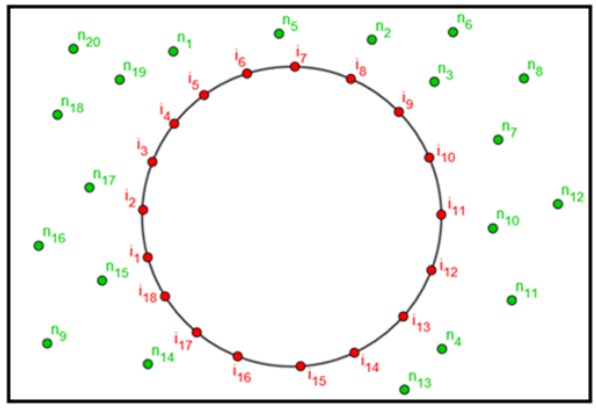

Gambar 5. Model Graf pada Tahap Awal masuknya Virus Covid-19 
Berdasarkan Gambar 5, terlihat bahwa terdapat himpunan vertex-vertex berwarna merah dengan notasi $i_{k}$ dimana $k=1,2, \cdots, 18$ yang menunjuk-kan elemen himpunan orang yang terinfeksi Covid-19 pada tahap awal. Himpunan orang yang terinfeksi Covid-19 tersebut membentuk graf siklus dengan 18 vertex. Kemudian, terdapat vertex-vertex berwarna hijau diluar graf siklus yang dinotasikan dengan $n_{k}$ dengan $k=1,2, \cdots k$ yang menunjukkan elemen himpunan orang yang rentan terinfeksi Covid-19.

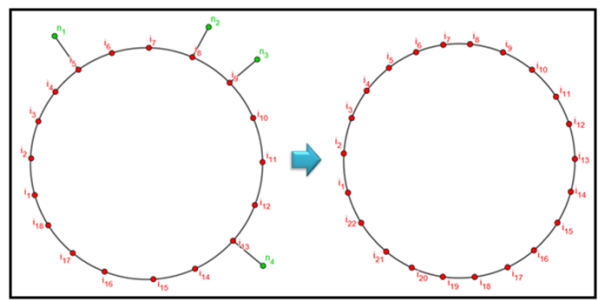

Gambar 6. Model Graf Pertumbuhan Virus Covid-19 pada Hari Ke-1

Berdasarkan Gambar 6 terlihat bahwa terdapat 4 vertex hijau yang dinotasikan dengan $n_{1}, n_{2}, n_{3}$, dan $n_{4}$ bertetangga dengan 4 vertex merah $i_{5}, i_{8}, i_{9}$, dan $i_{13}$ yang menunjukkan bahwa terjadinya proses menginfeksi oleh orang yang terinfeksi Covid-19 terhadap orang yang rentan. Orang yang rentan tersebut telah terinfeksi Covid-19 kemudian berpindah ke himpunan orang yang terinfeksi Covid-19 dan membentuk graf siklus baru dengan 22 vertex. Graf siklus baru dengan 22 vertex tersebut merupakan himpunan jumlah orang yang terinfeksi Covid-19 pada hari pertama. Keempat vertex yang telah terinfeksi tersebut juga berkemungkinan menginfeksi orang yang rentan lainnya. Hal yang sama berlaku pula untuk jumlah penderita pada hari ke- $n$ lainnya berdasarkan prediksi perhitungan yang telah diperoleh sebelumnya.

\section{Kesimpulan}

Berdasarkan hasil pada Bab pembahasan, maka dapat disimpulkan bahwa jumlah orang yang terinfeksi virus Covid-19 dengan laju pertumbuhan tak konstan dapat diprediksi dengan model berikut:

$$
I_{n}=\left(1+R_{n}\right)\left(1+R_{n-1}\right)\left(1+R_{n-2}\right) \cdots\left(1+R_{1}\right) I_{0} .
$$

Selanjutnya, jumlah orang yang terinfeksi pada $n$ hari kedepan dapat ditentukan dengan cepat dan mudah dengan menggunakan program Matlab. Hasil yang diperoleh dapat direpresentasikan ke dalam model pertumbuhan virus Covid-19 melalui penggunaan teori graf.

\section{Ucapan Terimakasih}

Penulis mengucapkan terimakasih kepada Ibu Dr.Lyra Yulianti, Bapak Dr.Ahmad Iqbal Baqi, dan Ibu Radhiatul Husna, M.Si yang telah memberikan masukan dan 
saran dalam penyempurnaan penulisan artikel ini.

\section{Daftar Pustaka}

[1] Bhapkar, H. R., Mahalle, P., Dhotre, P. S. 2020. Virus Graph and Covid-19 Pandemic: A Graph Theory Approach. Preprints 2020, 2020040507.

[2] Bondy, J.A. dan Murty, U.S.R. 1976. Graph Theory with Application. The Macmillan Press LTD, London.

[3] Gog, J., Thomas, R., Freiberger, M. 2020. The Growth Rate of COVID-19. Plus Magazine. 11 Juni 2020.

[4] Mankiw, N.G. 2018. Principles of Macroeconomics. Eight Edition. Cengage Learning, USA.

[5] Rosen, K. H. 2019. Discrete Mathematics and Its Applications. Eight Edition. Mc Grew Hill.

[6] WHO. 2020. https://www.who.int/dg/speeches/detail/who-director-general-sremarks-at-the-media-briefing-on-2019-ncov-on-11-february-2020 